Eur J Clin Chem Clin Biochem

1995; 33:775-783

(c) 1995 Walter de Gruyter \& Co.

Berlin - New York

\title{
Differential Induction of Peroxisomal Enzymes by Hypolipidaemics in Human (HepG2) and Rat (MH1C1) Hepatoma Cell Lines ${ }^{1}$ )
}

\author{
By Herbert Stangl ${ }^{1}$, Werner Kovacs ${ }^{1}$, Peter Böck ${ }^{2}$ and Karl Kremser ${ }^{1}$ \\ 1 Institut für Medizinische Chemie der Universität Wien, Wien, Austria \\ 2 Institut für Histologie der Veterinärmedizinischen Universität Wien, Wien, Austria
}

(Received May 22/July 25, 1995)

Dedicated to Professor Dr: Erich Kaiser on the occasion of his 70th birthday

Summary: Human (HepG2) and rat (MH1C1) hepatoblastoma cells were incubated with different concentrations of the hypolipidaemics cetaben, clofibrate and thyroxine. The enzymatic activities of catalase, peroxisomal bifunctional enzyme, succinate dehydrogenase, and 3-oxoacyl-CoA thiolase were measured. In order to determine the point of regulation of the enzymatic activities Northern and Slot blot experiments with probes for peroxisomal bifunctional enzyme, catalase and fatty acyl CoA oxidase were performed on total RNA. Catalase activity was enhanced in HepG 2 cells treated with $3 \mathrm{mmol} / \mathrm{l}$ clofibric acid to $135 \%$ of control and the mRNA value to 2.6 fold, whereas in cetaben treated cells the enhancement (up to $119 \%$ of control) was less pronounced. In $\mathrm{MH} 1 \mathrm{Cl}$ cells catalase activity was not changed by any of the drugs. The activity of the peroxisomal bifunctional enzyme was not affected in HepG2 cells by clofibric acid and cetaben, whereas the mRNA level was elevated to 2.3 fold by $10 \mu \mathrm{mol} / \mathrm{l}$ cetaben. At high concentrations of cetaben all enzyme activities were decreased in both cell lines due to its high cytotoxicity. Our data show that, due to the differences in the genomic organisation, the regulation of the enzyme activities is different in human and rat, but the results from the human and rat hepatoblastoma cells correlate with the findings in whole man and rat, so that a human in vitro system is more suitable for pharmacological tests. These results suggest that the human hepatoma cell line HepG2 may be a useful model system for studies of the influence of hypolipidaemics on the peroxisomal enzyme system.

\section{Introduction}

Peroxisomes are ubiquitous subcellular organelles which play important metabolic roles in nearly all animal cells

\footnotetext{
1 Supported by "Medizinisch-Wissenschaftlicher Fonds des Bürgermeisters der Bundeshauptstadt Wien"

2) Enzymes:

(Fatty) acyl CoA oxidase, acyl-CoA : oxygen oxidoreductase (EC 1.3.3.-)

Catalase, hydrogen=peroxide : hydrogen-peroxide oxidoreductase (EC 1.11.1.6)

Peroxisomal bifunctional enzyme, enoyl-CoA hydratase, and 3-hydroxyacyl-CoA dehydrogenase (EC 4.2.1.17 and EC 1.1.1.35)

Succinate dehydrogenase, succinate : (acceptor) oxidoreductase (EC 1.3.99.1)

(3-oxoacyl-CoA) Thiolase, Acyl-CoA acetyl-CoA acyltransferase (EC 2.3.1.16)
}

(1). They contain hydrogen peroxide-producing oxidases like fatty acyl-CoA oxidase ${ }^{2}$ ) and catalase ${ }^{2}$ ) for the detoxification of hydrogen peroxide (1). The amount of the peroxisomal fraction in rodent liver cells increases severalfold upon treatment with a variety of structurally different compounds such as hypolipidaemic drugs, phthalates, thyroxine and fatty acids (2). This process, known as peroxisome proliferation, increases the cellular capacity of the $\beta$-oxidation of very long-chain fatty acids by the induction of peroxisomal enzymes (2). Nevertheless, the response in human and non-human primates is much less pronounced than that observed in the rat and mouse (for review see $(3,4)$ ). Fibric acid derivatives are a well known group of hypolipidaemic drugs, mainly used for the treatment of hyperlipidaemia in human (5). 
The model fibrate clofibric acid (2-(4-chlorophenoxy)2-methylpropionic acid), one of the best characterized hypolipidaemic agents, is known to produce a profound hepatomegalic response, including proliferation of hepatic endoplasmic reticulum, mitochondria and peroxisomes after chronic treatment of rodents (6).

A different class of chemicals, lowering the concentration of lipids in blood and also noted for peroxisome proliferative efficiency, is represented by several alkylaminobenzoic acids (7). Chandoga et al. (8) have reported on the effect of cetaben (sodium $p$-hexadecyl aminobenzoate), a representative of this class of non fibrate peroxisome proliferators, on the activities of peroxisomal enzymes in liver and kidney of rats, but little is known about their effects in humans.

Like clofibrate, thyroid hormones lead to proliferation of liver peroxisomes (9). Furthermore, thyroid hormones increase the peroxisomal fatty acid $\beta$-oxidation, presumably by inducing acyl-CoA oxidase (10), the rate limiting enzyme of this pathway (11). Various models describe the modulation of thyroid hormone action by differential mechanisms via homo- or heterodimerization with nuclear receptors (12).

The regulation of the induction of peroxisomal enzymes seems to be different in different species $(4,13)$. In rat a single acyl-CoA oxidase gene is present, which gives rise to two different mRNAs by differential splicing (14). Schepers et al. (15) identified two different fatty acyl-CoA oxidases in rat liver, one of which is inducible by clofibrate. Only one gene for enoyl-CoA hydratase : 3-hydroxyacyl-CoA dehydrogenase has been identified in rat (16), which is inducible. Finally, two genes for peroxisomal 3-oxoacyl-CoA thiolase are present in rat; one is inducible by clofibrate (17). Thus, entirely different mechanisms are responsible for the induction of individual peroxisomal $\beta$-oxidation enzymes in rodents by clofibrate, e.g.

(a) enhanced synthesis of a specific mRNA formed by alternative splicing of the transcript of a single gene (acyl-CoA oxidase), or

(b) enhanced transcription of a separate gene (thiolase), or

(c) enhanced transcription of a single gene (enoyl-CoA hydratase : 3-hydroxyacyl-CoA dehydrogenase) (13).

The situation in human appears to be different, as there is only a single gene for peroxisomal 3-oxoacyl-CoA thiolase (18), and also only one for fatty acyl-CoA oxidase, with properties similar to those of the non-inducible isoform in rat liver (19). This may be related to the fact that compounds like clofibrate do not induce peroxisomal $\beta$-oxidation enzymes in primates (20). In this respect it will be of interest to see if the response in primates correlates with the response in human.

The aim of the present study was to show the difference in the regulation of induction of peroxisomal enzymes by peroxisomal proliferators in comparison of rats and human. A rat and a human hepatoma cell line, $\mathrm{MH} 1 \mathrm{Cl}$ and HepG2, respectively, were selected as model systems. In our approach we were able to demonstrate the differential regulation of the induction of peroxisomal enzymes as a response to the application of hypolipidaemic drugs on cell cultures of human and rat liver cells.

\section{Materials and Methods}

Cell culture

HepG2 cells, derived from a human hepatoblastoma, were obtained from the American Tissue Culture Collections (Rockville, USA) and grown in Dulbecco's Modified Eagles Medium (GIBCO/BRL; Paisly, UK) supplemented with foetal bovine serum (GIBCO/BRL; Paisley, UK), volume fraction 0.1 . The $\mathrm{MH} 1 \mathrm{Cl}$ cell line, derived from the Morris 7795 rat hepatoma, was obtained from the German Collection of Microorganisms and Cell Cultures (Braunschweig, Germany) and grown in Dulbecco's Modified Eagles Medium supplemented with foetal bovine serum, volume fraction 0.15 . All media were supplemented with $100 \times 10^{3} \mathrm{IU} / 1$ penicillin $\mathrm{G}$ and 100 $\mathrm{mg} / \mathrm{l}$ streptomycin. The cells were kept at $37^{\circ} \mathrm{C}$ in a humidified atmosphere of $10 \% \mathrm{CO}_{2}$ and $90 \%$ air (isobaric).

For all experiments cells were plated at a density of $2 \times 10^{6}$ cells per Petri dish (diameter $100 \mathrm{~mm}$ ) and grown to confluence. All incubation media were prepared by adding the appropriate volume of a stock solution of test compound. Clofibric acid (stock solution: $1 \mathrm{~mol} / \mathrm{l})$ was dissolved in dimethylsulphoxide. Cetaben $(25 \mathrm{mmol} / \mathrm{l}$ stock solution) was suspended in phosphate buffered saline $(8 \mathrm{~g} / \mathrm{l}$ $\mathrm{NaCl}, 0.2 \mathrm{~g} / \mathrm{KCl}, 0.2 \mathrm{~g} / \mathrm{K} \mathrm{KH}_{2} \mathrm{PO}_{4}, 0.1 \mathrm{~g} / \mathrm{CaCl}_{2}, 0.1 \mathrm{~g} / 1 \mathrm{MgCl}_{2}$ - $6 \mathrm{H}_{2} \mathrm{O}, 2.9 \mathrm{~g} / 1 \mathrm{Na}_{2} \mathrm{HPO}_{4} \cdot 12 \mathrm{H}_{2} \mathrm{O}, \mathrm{pH}=7.2$ ).

Triiodothyronine (50 mmol// stock solution) was prepared in 0.01 $\mathrm{mol} / \mathrm{l} \mathrm{NaOH}$. Incubation media were sonicated for $10 \mathrm{~min}$ at room temperature before use. Treatment of the confluent monolayers was commenced by replacing the culture media with incubation media supplemented with the test compounds. Incubations were carried out for 24 hours. The monolayers were washed two times with phosphate buffered saline. The cells were detached by means of trypsin-EDTA (0.5 g/l trypsin, $0.2 \mathrm{~g} / 1$ EDTA) for $5 \mathrm{~min}$ at $37^{\circ} \mathrm{C}$. Cell suspensions were sedimented for $5 \mathrm{~min}$ at $300 \mathrm{~g}$, resuspended, centrifuged again and suspended in ice cold phosphate buffered saline.

\section{Enzyme assays}

For the determination of catalase activity, cells were incibated with $10 \mathrm{~g} / 1$ Triton $\mathrm{X}-100$ for 2 min prior to the assay.

For the determination of enzyme activities, cells were homogenised with a Potter homogeniser for $1 \mathrm{~min}$ at $1000 \mathrm{~min}^{-1}$ at $0^{\circ} \mathrm{C}$.

Succinate dehydrogenase was determined according to Kremser et al. (21). Enoyl-CoA hydratase : 3-hydroxyacyl CoA dehydrogenase (peroxisomal bifunctional enzyme) was estimated by measuring the crotonoyl-CoA dependent formation of NADH at $340 \mathrm{~nm}$ (22): The assay of thiolase was performed by measuring the thioester absorption band at $233 \mathrm{~nm}$ using acetoacetyl-CoA as a substrate (23). .Catalase was assayed according to Baudhuin et al. (24). The protein content in cell homogenates was measured according to the method of Bradford (25) using the Bio-Rad protein assay kit (Bio- 
Rad, Hercules, USA). All specific activities are expressed as mU/ mg protein.

\section{Preparation of RNA}

Total cellular RNA was prepared according to the method described by Sambrook et al. (26) from confluent HepG2 and $\mathrm{MH} 1 \mathrm{Cl}$ cells treated with the substances indicated. The RNA content was estimated by measuring the absorbance at $260 \mathrm{~nm}$. Total RNA was precipitated with ethanol and stored at $-70^{\circ} \mathrm{C}$.

Poly $\left(\mathrm{A}^{+}\right) \mathrm{RNA}$ was isolated using the PolyATtract mRNA isolation system III of Promega according to the manufacturer's instructions (Promega; Madison, USA).

\section{Northern- and slot-blot analysis}

RNA was separated by electrophoresis on $1 \%$ agarose gels under denaturing conditions and then transferred to Hybond-N membranes (Amersham; Little Chalfont, UK) by capillary blotting technique (26). RNA molecular weight marker II (Boehringer Mannheim; Mannheim, Germany) was used as size standard in RNA gel electrophoresis.

For slot-blot analysis total RNA was denatured with formaldehyde and applied to Hybond-N membranes. RNA was fixed to the membranes by UV-crosslinking. The probes used in the hybridisation procedures included restriction fragments of $P_{s t l}$ fragment of rat acyl CoA oxidase (686 bases) (27), Xbal fragment of human enoylCoA hydratase : 3-hydroxyacyl-CoA dehydrogenase $\left(1 \times 10^{3}\right.$ bases) (28), EcoRI fragment of human catalase $\left(2.2 \times 10^{3}\right.$ bases, personal communication; Prof. I. Singh), Pst fragment of rat catalase $\left(1 \times 10^{3}\right.$ bases) $(29), E c o R I$ fragment of human $\beta$-actin $(1.1$ $\times 10^{3}$ bases) (30) and PstI fragment of mouse $\beta$-actin $\left(1.1 \times 10^{3}\right.$ bases) (31).

cDNA probes were labelled with [ $\left.\alpha-{ }^{32} \mathrm{P}\right] \mathrm{dCTP}$ using the NEBlot Kit (New England Biolabs; Beverly, USA) (32). Membranes were prehybridised in a solution containing $500 \mathrm{~g} / 1$ formamide, 0.75 $\mathrm{mol} / 1 \mathrm{NaCl}, 75 \mathrm{mmol} / \mathrm{h}$ sodium citrate $(\mathrm{pH}=7), 0.4 \mathrm{~g} / 1$ Ficoll 400 , $0.4 \mathrm{~g} / 1$ polyvinylpyrrolidone, $0.4 \mathrm{~g} / 1$ bovine serum albumin (Fraction V), $1 \mathrm{~g} / \mathrm{l} \mathrm{SDS}, 200 \mathrm{mg} / \mathrm{l}$ salmon sperm DNA and $100 \mathrm{~g} / \mathrm{l}$ dextran sulphate at $42^{\circ} \mathrm{C}$ for $2 \mathrm{~h}$ and after addition of the denatured probes hybridisation was carried out overnight. Membranes were washed twice for $15 \mathrm{~min}$ in $0.3 \mathrm{~mol} / \mathrm{l} \mathrm{NaCl}, 30 \mathrm{mmol} / 1$ sodium citrate $(\mathrm{pH}=7), 1 \mathrm{~g} / 1 \mathrm{SDS}$, at room temperature, followed by two washes for $15 \mathrm{~min}$ at $42^{\circ} \mathrm{C}$ in $0.15 \mathrm{~mol} / 1 \mathrm{NaCl}, 15 \mathrm{mmol} / 1$ sodium citrate $(\mathrm{pH}=7), 1 \mathrm{~g} / 1$ SDS. Membranes were autoradiographed using Kodak X-Omat films and intensifying screens (Kodak; Rochester, USA).

After autoradiography, the RNA filters were washed using 0.005 mol/l Tris- $\mathrm{HCl}(\mathrm{pH} 8.0), 0.002 \mathrm{~mol} / 1 \mathrm{EDTA}$ and $0.02 \mathrm{~g} / \mathrm{l}$ Ficoll $400,0.02 \mathrm{~g} / 1$ polyvinylpyrrolidone, $0.02 \mathrm{~g} / \mathrm{l}$ bovine serum albumin (Fraction V), $0.05 \mathrm{~g} / 1$ SDS for $2 \mathrm{~h}$ at $65^{\circ} \mathrm{C}$ and reprobed. Membranes treated this way revealed no signs of diminished quality after reprobing. Human and mouse $\beta$-actin cDNA were used to rehybridise the membranes and served as an internal standard for the normalisation of the RNA levels. Slot blots were quantified by counting each blot with the InstantImager (Canberra Packard; Meriden, USA), and densitometry was performed using the Pharmacia Image Master (Pharmacia; Uppsala, Sweden).

\section{Cytotoxicity assay}

Cytotoxicity was assessed by measurement of the activity of mitochondrial dehydrogenases of viable cells (33). Cells were seeded on $1 \mathrm{ml}$ microtitration plates at cell densities of $10 \times 10^{6} / 1,50$ $\times 10^{6} / 1$, and $100 \times 10^{6} / 1$. Twentyfour hours after plating cells were treated with the test compounds for 24 hours. 3-(4,5-Dimethylthiazol-2-yl)-2,5-diphenyl-tetrazolium bromide (MTT) was added directly to the wells. After 3 hours at $37^{\circ} \mathrm{C}$ media was removed, the formazan was solubilized in dimethylsulphoxide/acetic acid/SDS (100 g/l SDS, $100 \mathrm{mmol} / \mathrm{l}$ acetic acid in dimethylsulphoxide) and the plates were read on a Microplate Autoreader (Bio-Tek Instruments, Winooski, USA) at $570 \mathrm{~nm}$. The formazan is produced proportional to the dehydrogenase activity.

\section{Morphology}

After treatment with the test compound cells were harvested and washed twice with ice-cold phosphate buffered saline and fixed in ice-cold glutaraldehyde $(25 \mathrm{~g} / \mathrm{l})$ in $0.2 \mathrm{~mol} / \mathrm{l}$ phosphate buffer, $\mathrm{pH}$ 7.2. After 3 hours of fixation the cells were washed with phosphate buffered saline and postfixation with $1 \%$ osmium tetroxide was employed. The specimens were washed in distilled water, dehydrated in a series of graded ethanol solutions and routinely embedded in Epon 812. Ultrathin section were cut with an ultramicrotome (Reichert, Vienna, Austria) and examined in a Zeiss EM9S/2 electron microscope (Zeiss, Oberkochen, Germany).

\section{Statistics}

Statistical comparison between the control groups and the treated groups were made, using analysis of variance followed by Student's t-test.

\section{Results}

\section{Morphology}

Electron microscopical comparisons of hepatoma cell lines (treated and untreated) were carried out to confirm proliferation by the application of clofibric acid. HepG2 cells presented inconspicuously. They were provided with abundant free ribosomes, contained short segments of rough endoplasmic reticulum, Golgi areas and cristaetype mitochondria (fig. 1). Peroxisomes were rarely identified. These organelles were mostly oval in shape

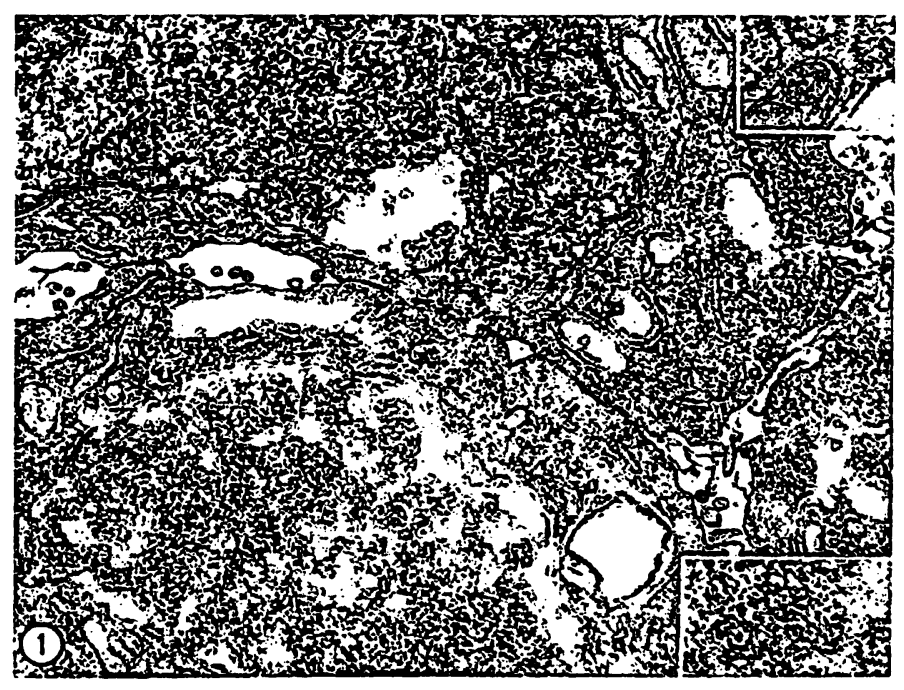

Fig. 1 Electron micrographs showing peroxisomes in HepG2 cells, control preparation with dimethylsulphoxide. Cells contain abundant ribosomes, segments of rough endoplasmic reticulum, Golgi regions, mitochondria, and a few lipid droplets. Microbodies are rarely seen (inserts); they represent microperoxisomes with granular matrix but without a crystalline core. Magnification: $\times 1900$; insert $\times 8900$. 
and measured $0.2-0.25 \mu \mathrm{m}$ in diameter. They contained granular matrix material of moderate electron density and were confined by a single membrane (fig. 1, inserts). After treatment with clofibric acid, the number of microperoxisomal profiles was increased but morphology and size of the individual organelles appeared unchanged (fig. 2).

Comparable results were obtained with the rat hepatoma cell line $\mathrm{MHlCl}$ (results not shown).

\section{Cytotoxicity}

The toxicological effects of the compounds used were verified by measurement of the mitochondrial dehydrogenases of the cells in order to estimate the concentra-

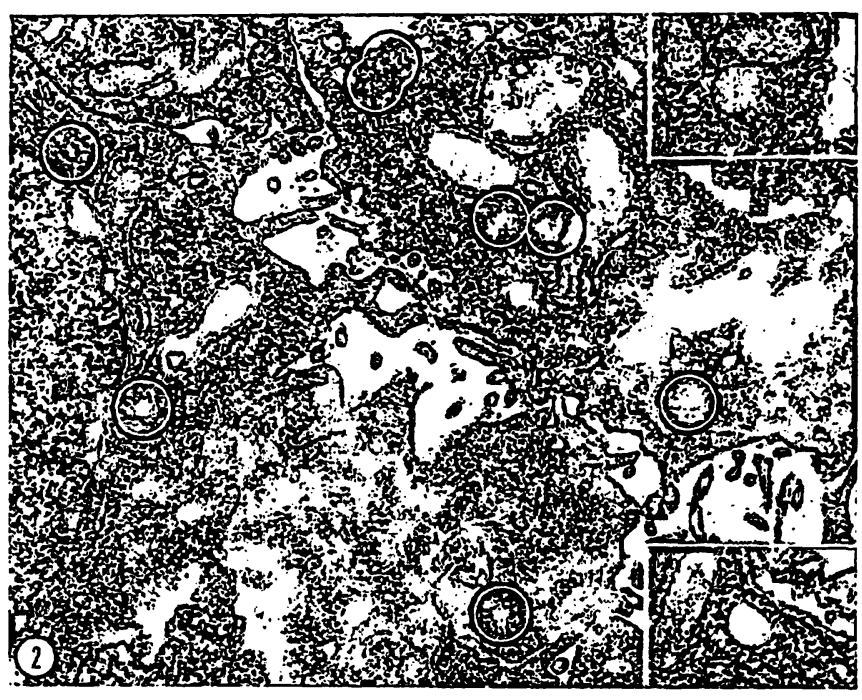

Fig. 2 Electron micrographs showing peroxisomes in HepG2 cells, cells treated with $3 \mathrm{mmol} / \mathrm{l}$ clofibric acid. Gross morphology of HepG2 cells closely resembles that of control cells (compare with fig. 1). The number of microperoxisomes, however, is increased (encircled regions; two of them are shown at higher magnification in the inserts). Note that mitochondrial volume also appears slightly enlarged. Magnification: $\times 1900$; insert $\times 8900$.

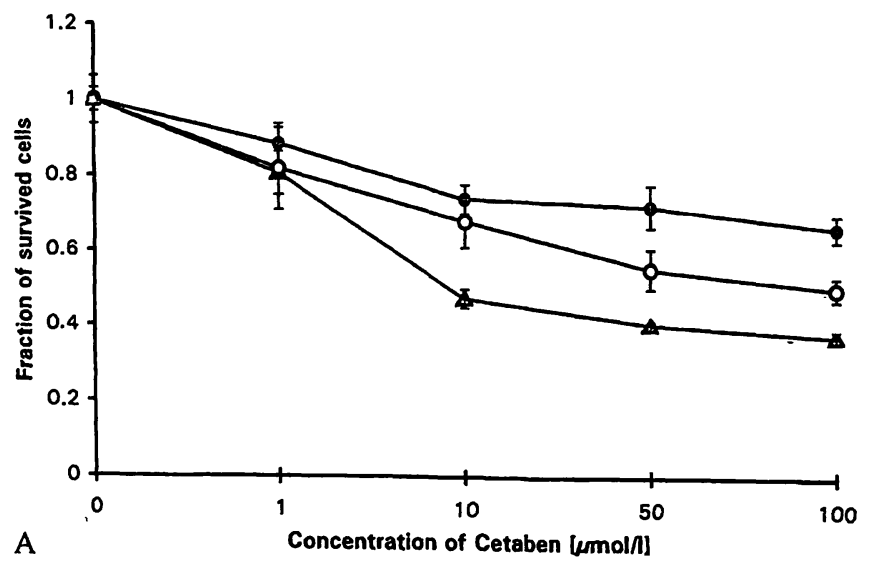

Fig. 3A-B Comparison of the dose response of HepG2 and $\mathrm{MH} 1 \mathrm{Cl}$ cell lines at different concentrations of cetaben. Fractional survival of HepG2 (Panel A) and MH1Cl (Panel B) using the cytotoxicity assay (see Method's section). Filled circles: tion range of cytotoxicity, because toxicological effects need to be avoided for proliferation experiments. The results of the cytotoxicity assays indicate that clofibric acid and triiodothyronine do not influence the viability of both cell lines at concentrations below $5 \mathrm{mmol} / \mathrm{l}$ and $100 \mu \mathrm{mol} / \mathrm{l}$, respectively (data not shown). Cetaben treated cells already show a significant response at 10 $\mu \mathrm{mol} / 1$. The fractional survivals of $\mathrm{HepG} 2$ and $\mathrm{MH} 1 \mathrm{Cl}$ cell lines at a number of 100000 cells per well treated with $100 \mu \mathrm{mol} / \mathrm{l}$ cetaben were $66 \%$ and $45 \%$ of control $(\mathrm{p}<0.001)$ respectively (fig. $3: \mathrm{A}-\mathrm{B})$. The cytotoxic effect was more pronounced at a cell number of 10000 , where the fractional survival for both cell lines was $37 \%$ $(p<0.001)$. The rat hepatoma cell line showed a greater sensitivity at higher cell number towards cetaben than the human cell line (fig. 3: A-B). Since cytotoxicity was lower at higher cell densities confluent monolayers were used for all experiments. These findings agree with previous morphological studies on rat hepatocytes (34).

\section{Enzymes}

In order to quantify the difference of the induction of peroxisomal proliferation between human (HepG2) and rat $(\mathrm{MH} 1 \mathrm{Cl})$ cells, peroxisomal and mitochondrial enzymatic activities were determined.

In HepG2 $3 \mathrm{mmol} / \mathrm{l}$ clofibric acid had no effect on thiolase and the peroxisomal bifunctional enzyme activities. The activity of catalase was increased from $19.9 \pm 2.1$ to $26.7 \pm 2.7 \mathrm{mU} / \mathrm{mg}(\mathrm{p}<0.01)$, succinate dehydrogenase activity from $13.5 \pm 0.7$ to $18 \pm 2.5 \mathrm{mU} / \mathrm{mg}$ by $3 \mathrm{mmol} / \mathrm{l}$ clofibric acid (see tab. 1A). Catalase activity was increased by $10 \mu \mathrm{mol} / 1$ and $100 \mu \mathrm{mol} / \mathrm{l}$ cetaben to about $120 \%$ of control $(p<0.01$; control activity: 17.7 $\pm 1.2 \mathrm{mU} / \mathrm{mg}$ ), whereas the peroxisomal bifunctional enzyme was not affected (control activity: $37.9 \pm 4.4$ $\mathrm{mU} / \mathrm{mg}$ ). Ten $\mu \mathrm{mol} / \mathrm{l}$ cetaben did not alter the activity

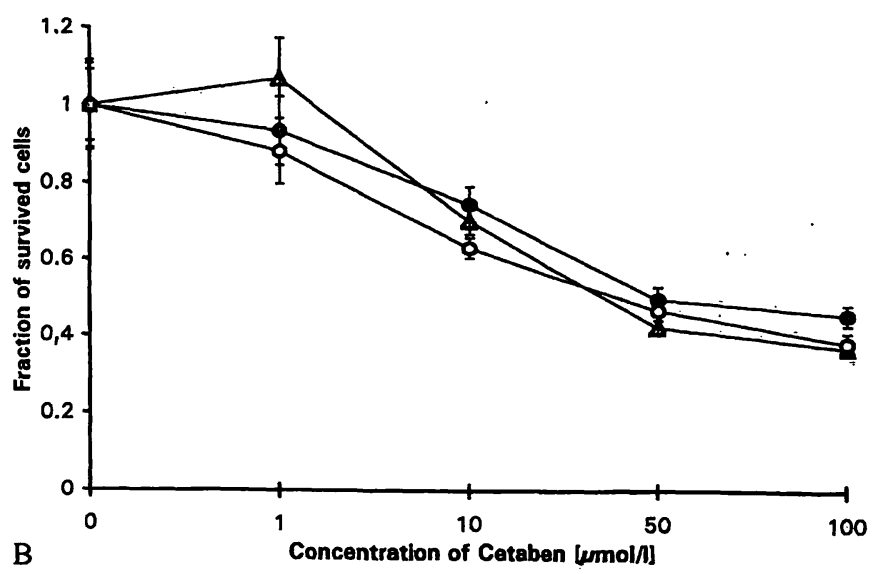

cell number $=100.000$; open circles: cell number $=50.000$; open triangles: cell number $=10.000$. All experiments were performed in triplicate. 
of succinate dehydrogenase, whereas the activity was decreased by $100 \mu \mathrm{mol} / 1$ cetaben from $11.8 \pm 1.0$ to 8.7 $\pm 1.4 \mathrm{mU} / \mathrm{mg}(\mathrm{p}<0.01)$. Thiolase activity was slightly

Tab. 1 Relative specific activities of catalase, the peroxisomal bifunctional enzyme, succinate dehydrogenase and thiolase of HepG2 (Panel A) and MHICl (Panel B) cells after treatment for 24 hours with the indicated compounds.

\begin{tabular}{llll}
\hline Compound & $\begin{array}{l}\text { Clofibric } \\
\text { acid } \\
3 \mathrm{mmol} / 1\end{array}$ & Cetaben & \\
\cline { 2 - 4 } & $30 \mu \mathrm{mol} / 1$ & $100 \mu \mathrm{mol} / 1$ \\
\hline
\end{tabular}

A: HepG2 cells

\begin{tabular}{lccr}
\hline Catalase & $\begin{array}{r}135 \pm 10^{*} \\
\mathrm{n}=5\end{array}$ & $\begin{array}{r}119 \pm 3^{*} \\
\mathrm{n}=4\end{array}$ & $\begin{array}{r}118 \pm 8^{*} \\
\mathrm{n}=7\end{array}$ \\
Thiolase & $96 \pm 5$ & $119 \pm 8$ & $89 \pm 12$ \\
& $\mathrm{n}=4$ & $\mathrm{n}=4$ & $\mathrm{n}=4$ \\
Bifunctional & $116 \pm 12$ & $97 \pm 7$ & $96 \pm 12$ \\
enzyme & $\mathrm{n}=4$ & $\mathrm{n}=5$ & $\mathrm{n}=5$ \\
Succinate & $133 \pm 14^{* *}$ & $110 \pm 17$ & $75 \pm 16^{*}$ \\
dehydrogenase & $\mathrm{n}=4$ & $\mathrm{n}=5$ & $\mathrm{n}=5$ \\
\hline B: MH1C1 cells & & & \\
\hline Catalase & $104 \pm 8$ & $104 \pm 10$ & $106 \pm 11$ \\
& $\mathrm{n}=4$ & $\mathrm{n}=4$ & $\mathrm{n}=4$ \\
Thiolase & $125 \pm 8$ & $129 \pm 8^{* *}$ & $123 \pm 14$ \\
& $\mathrm{n}=3$ & $\mathrm{n}=3$ & $\mathrm{n}=3$ \\
Bifunctional & $112 \pm 25$ & $89 \pm 19$ & $95 \pm 4$ \\
enzyme & $\mathrm{n}=4$ & $\mathrm{n}=3$ & $\mathrm{n}=4$ \\
Succinate & $118 \pm 30$ & $75 \pm 10$ & $57 \pm 16^{*}$ \\
dehydrogenase & $\mathrm{n}=4$ & $\mathrm{n}=3$ & $\mathrm{n}=4$ \\
\hline
\end{tabular}

The values are given as $\%$ of control $\pm \%$ SEM. ${ }^{*} \mathrm{p}<0.01$; ${ }^{* *} \mathrm{p}<0.02 ; \mathrm{n}$ indicates the number of experiments. The specific activities are given in the result section.

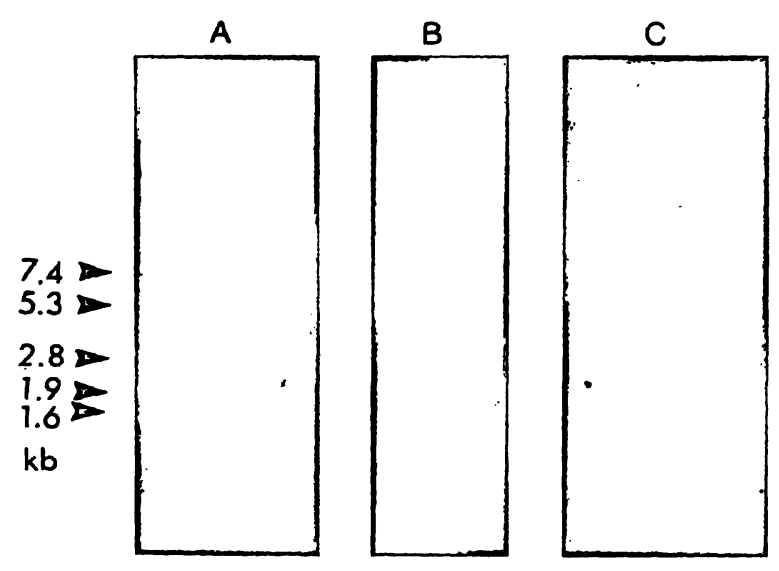

Fig. 4 Northern blot analysis of HepG2 cells after hybridisation with a cDNA probe for human $\beta=$ actin (panel $A$ ), a cDNA probe for human catalase (panel $B$ ) and a probe derived from the human peroxisomal bifunctional enzyme cDNA (panel C). RNA size marker is indicated on the left. The mRNA sizes are: $\beta$-actin 2.1 $\times 10^{3}$ bases, catalase $2.7 \times 10^{3}$ bases and peroxisomal bifunctional enzyme $4.6 \times 10^{3}$ bases. enhanced by $10 \mu \mathrm{mol} / 1$ cetaben from $319.5 \pm 43.6$ to $379.3 \pm 30.1 \mathrm{mU} / \mathrm{mg}$, but $100 \mu \mathrm{mol} / 1$ cetaben slightly decreased the activity to $283.6 \pm 35 \mathrm{mU} / \mathrm{mg}$ (tab. $1 \mathrm{~A}$ ). In HepG2 cells the activities of all enzymes were not affected by treatment with $10 \mu \mathrm{mol} / \mathrm{l}$ and $100 \mu \mathrm{mol} / \mathrm{l}$ triiodothyronine (data not shown).

Three $\mathrm{mmol} / \mathrm{l}$ clofibric acid did not increase the activities of catalase (control activity $71.1 \pm 1.9 \mathrm{mU} / \mathrm{mg}$ ), succinate dehydrogenase (control activity $7.1 \pm 2.5 \mathrm{mU} /$ $\mathrm{mg}$ ) and the peroxisomal bifunctional enzyme (control activity $52.9 \pm 5.4 \mathrm{mU} / \mathrm{mg}$ ) in $\mathrm{MH} 1 \mathrm{Cl}$ cells, whereas thiolase activity was enhanced from $166.5 \pm 21.9$ to $207.6 \pm 12.5 \mathrm{mU} / \mathrm{mg}$ (tab. 1B). The mitochondrial marker succinate dehydrogenase was decreased by 10 $\mu \mathrm{mol} / 1$ cetaben from $8.9 \pm 1.2$ to $6.7 \pm 0.7 \mathrm{mU} / \mathrm{mg}$ and further significantly decreased by $100 \mu \mathrm{mol} / \mathrm{l}$ cetaben to $5.1 \pm 0.8 \mathrm{mU} / \mathrm{mg}(\mathrm{p}<0.01)$ in $\mathrm{MH} 1 \mathrm{Cl}$. Thiolase activity was enhanced by $10 \mu \mathrm{mol} / 1$ and $100 \mu \mathrm{mol} / 1$ cetaben from $172.4 \pm 8.2$ to $222.2 \pm 18.6 \mathrm{mU} / \mathrm{mg}(\mathrm{p}<0.02)$ and to $212.8 \pm 30.1 \mathrm{mU} / \mathrm{mg}$. Catalase and the peroxisomal bifunctional enzyme showed no response to the treatment with cetaben in MH1C1 cells (tab. 1B). The activities of all enzymes were not significantly affected by treatment with $10 \mu \mathrm{mol} / 1$ and $100 \mu \mathrm{mol} / 1$ triiodothyronine in $\mathrm{MH} 1 \mathrm{Cl}$ cells (data not shown).

\section{RNA analysis}

Northern blot experiments with mRNA of HepG2 (fig. 4) and $\mathrm{MH1Cl}$ (fig. 5) were carried out to confirm the identity of the probes.

In order to determine whether the observed variations in catalase, peroxisomal bifunctional enzyme and acylCoA oxidase activities resulted from increased expres-

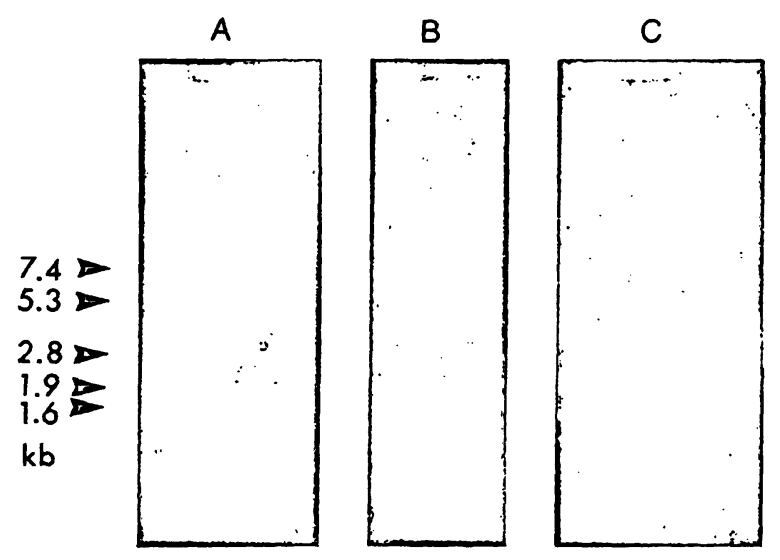

Fig. 5 Northern blot analysis of $\mathrm{MHLCl}$ cells after hybridisation with a cDNA probe for mouse $\beta$-actin (panel $A$ ), a cDNA probe for rat catalase (panel $B$ ) and a cDNA probe for rat fatty acyl-CoA oxidase (panel C). RNA size marker is indicated on the left. The mRNA sizes are: catalase $2.8 \times 10^{3}$ bases, fatty acyl-CoA oxidase $4.2 \times 10^{3}$ bases and $\beta$-actin $2.2 \times 10^{3}$ bases. 
sion of the corresponding genes, we determined the cellular mRNA levels after 24 hours of incubation of HepG2 and $\mathrm{MH} 1 \mathrm{Cl}$ cells with $3 \mathrm{mmol} / 1$ clofibric acid, $10 \mu \mathrm{mol} / 1$ and $100 \mu \mathrm{mol} / 1$ cetaben with different amounts of RNA. Cell monolayers from the corresponding subcultures, which were used for determination of enzyme activities or cytotoxicity assays, were incubated in parallel in Dulbecco's Modified Eagles medium with or without peroxisomal proliferators. mRNA levels were assayed by slot-blotting, using specific ${ }^{32}$ P-labelled probes (fig. 6,7 and 8), as described in Materials and Methods. The $\beta$-actin mRNA level was used as an internal standard.

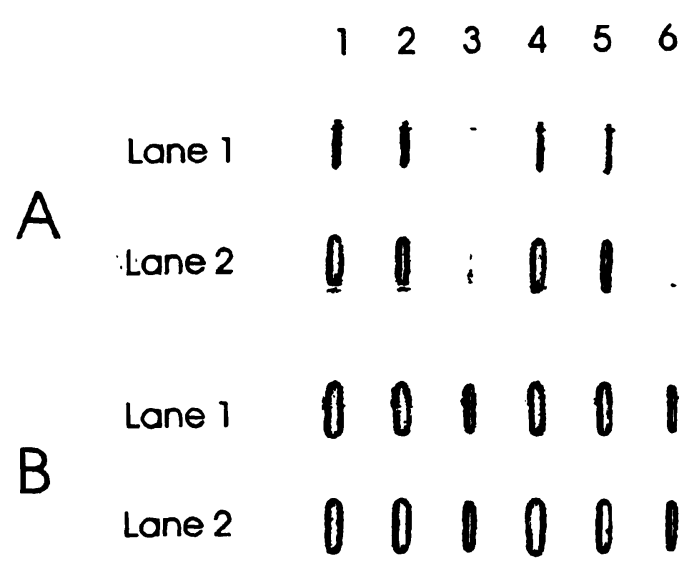

Fig. 6 Slot blot analysis of the effect of clofibric acid on catalase in HepG2 cells. HepG2 cells were exposed to $3 \mathrm{mmol} / \mathrm{l}$ clofibric acid for $24 \mathrm{~h}$. Total RNA was purified, denatured and applied to the membrane (slots 1, 4: $20 \mu \mathrm{g}$; slots 2, 5: $10 \mu \mathrm{g}$; slots 3, 6: $1 \mu \mathrm{g}$; lane 1: control cells; lane 2: $3 \mathrm{mmol} / 1$ clofibric acid). The membrane was hybridised with ${ }^{32} \mathrm{P}$-labelled cDNAs for catalase (panel A), washed and rehybridised with a probe for $\beta$-actin (panel B).$$
123 \quad 4 \quad 4 \quad 5 \quad 6
$$ \\ Lane 1 \\ A \\ Lane 2

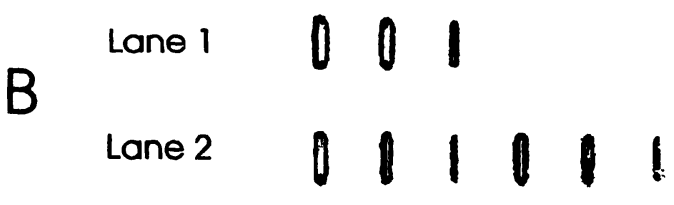

Fig. 7 Slot blot analysis of the effect of cetaben on the peroxidase bifunctional enzyme in HepG2 cells. HepG2 cells were exposed to $10 \mu \mathrm{mol} / \mathrm{l}$ (slots $1,2,3$ ) and $100 \mu \mathrm{mol} / 1$ (slots $4,5,6$ ) cetaben for $24 \mathrm{~h}$. Total RNA was purified, denatured and applied to the membrane; lane 1: control cells (slot 1: $20 \mu \mathrm{g}$; slot 2: $10 \mu \mathrm{g}$; slot 3: $1 \mu \mathrm{g}$ ); lane 2: Cetaben (slots 1, 4: $20 \mu \mathrm{g}$; slots 2, 5: $10 \mu \mathrm{g}$; slots 3, 6: $1 \mu \mathrm{g}$ ). The membrane was hybridised with ${ }^{32}$ P-labelled cDNAs for peroxisomal bifunctional enzyme (panel $A$ ), washed and rehybridised with a probe for $\beta$-actin (panel B).
As shown in table 2 catalase mRNA was 2.6 fold higher in HepG2 cells treated with $3 \mathrm{mmol} / 1$ clofibric acid than in controls $(p<0.001)$. The significant increase of mRNA levels induced by clofibric acid also correlates with the higher activity of catalase (tab. 1). Interestingly the mRNA levels of the peroxisomal bifunctional enzyme were not increased by $3 \mathrm{mmol} / \mathrm{l}$ clofibric acid
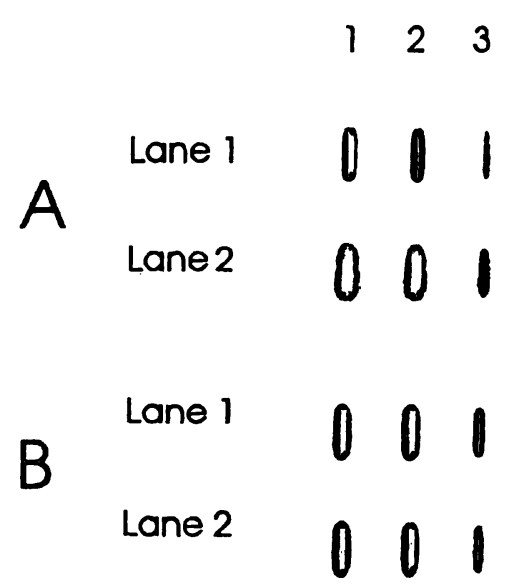

Fig. 8 Slot blot analysis of the effect of clofibric acid on fatty acyl-CoA oxidase in $\mathrm{MH} 1 \mathrm{Cl}$ cells. $\mathrm{MH} 1 \mathrm{Cl}$ cells were exposed to $3 \mathrm{mmol} / \mathrm{l}$ clofibric acid for $24 \mathrm{~h}$. Total RNA was purified, denatured and applied to the membrane (slot 1: $20 \mu \mathrm{g}$; slot 2: $10 \mu \mathrm{g}$; slot 3: $1 \mu \mathrm{g}$; lane 1: control cells; lane 2: $3 \mathrm{mmol} / \mathrm{l}$ clofibric acid). The membrane was hybridised with ${ }^{32} \mathrm{P}$-labelled cDNAs for fatty acyl-CoA oxidase (panel $A$ ), washed and rehybridised with a probe for $\beta$-actin (panel $B$ ).

Tab. 2 Relative mRNA levels of catalase and the peroxisomal bifunctional enzyme in HepG2 cells and of catalase and fatty acylCoA oxidase mRNAs in MH1Cl cells after treatment for $24 \mathrm{~h}$.

\begin{tabular}{|c|c|c|c|}
\hline \multirow[t]{2}{*}{ Cell line } & \multirow[t]{2}{*}{ Treatment } & \multicolumn{2}{|c|}{ Relative mRNA values } \\
\hline & & $\begin{array}{l}\text { human } \\
\text { catalase }\end{array}$ & $\begin{array}{l}\text { human peroxi- } \\
\text { somal bifunc- } \\
\text { tional enzyme }\end{array}$ \\
\hline \multirow[t]{4}{*}{ HepG2 } & $\begin{array}{l}\text { Clofibric acid, } \\
3 \mathrm{mmol} / \mathrm{l}\end{array}$ & $2.6 \pm 0.22 * *$ & $1.0 \pm 0.15$ \\
\hline & $\begin{array}{l}\text { Cetaben, } \\
10 \mu \mathrm{mol} / 1\end{array}$ & & $2.3 \pm 0.14^{*}$ \\
\hline & $\begin{array}{l}\text { Cetaben, } \\
100 \mu \mathrm{mol} / 1\end{array}$ & & $1.4 \pm 0.14$ \\
\hline & & rat catalase & $\begin{array}{l}\text { rat fatty acyl- } \\
\text { CoA oxidase }\end{array}$ \\
\hline \multirow[t]{2}{*}{$\mathrm{MH} 1 \mathrm{Cl}$} & $\begin{array}{l}\text { Clofibric acid, } \\
3 \mathrm{mmol} / \mathrm{l}\end{array}$ & $0.9 \pm 0.06$ & $1.8 \pm 0.29 * *$ \\
\hline & $\begin{array}{l}\text { Cetaben, } \\
100 \mu \mathrm{mol} / 1\end{array}$ & & $2.4 \pm 0.64^{*}$ \\
\hline
\end{tabular}

After autoradiography, the densities were recorded and expressed in conventional densitometric units to calculate the relative levels. Each value was divided by the corresponding mRNA $\beta$-actin value. Finally, the relative levels of mRNA in treated cells were divided by the relative values of parallel non-treated control cells. The ratios are given as mean $\pm \mathrm{SEM} ; \mathrm{n}=3 ;{ }^{*} \mathrm{p}<0.01,{ }^{* *} \mathrm{p}<0.001$ as compared with the corresponding control value. 
which correlates well with the enzyme activities in HepG2 (tab. 1).

The mRNA level for the peroxisomal bifunctional enzyme in HepG2 cells treated with $10 \mu \mathrm{mol} / 1$ cetaben was elevated significantly to 2.3 fold as compared with the control $(p<0.01)$, whereas treatment with $100 \mu \mathrm{mol} / 1$ cetaben did not cause a significant increase. These findings do not correlate with the enzymatic activities of the peroxisomal bifunctional enzyme which remained unchanged at all concentrations of cetaben.

The mRNA for fatty acyl-CoA oxidase of $\mathrm{MH1Cl}$ cells was increased 1.8 fold $(p<0.001)$ by $3 \mathrm{mmol} / 1$ clofibric acid which correlates well with the findings of Thangada et al. (34) using Ciprofibrate in primary hepatocyte cultures. Cetaben treated cells showed a similar increase in fatty acyl-CoA oxidase $(2.4$ fold, $\mathrm{p}<0.01)$ using 100 $\mu \mathrm{mol} / 1$ cetaben (tab. 2).

Catalase mRNA was not affected by $3 \mathrm{mmol} / \mathrm{l}$ clofibric acid (tab. 2) which parallels the enzymatic activity.

\section{Discussion}

The main objective of the present study was to show the difference in the regulation of the peroxisomal $\beta$ oxidation of a human (HepG2) and rat (MH1C1) cell line. In order to elucidate if the effects on the peroxisomal $\beta$-oxidation are correlated with the cytotoxicity of the chemicals a cytotoxicity assay was carried out. This assay indicates that clofibric acid and triiodothyronine at concentration of $5 \mathrm{mmol} / \mathrm{l}$ and $100 \mu \mathrm{mol} / \mathrm{l}$, respectively, are not toxic, whereas cetaben is highly toxic even at low concentrations $(100 \mu \mathrm{mol} / \mathrm{l})$. Therefore the effects of higher concentrations of cetaben on the peroxisomal $\beta$-oxidation are superimposed by its cytotoxicity. Succinate dehydrogenase, a mitochondrial marker enzyme, was used to check the status of the mitochondrial energy producing system to verify the energy state of the cells. Clofibric acid enhances succinate dehydrogenase whereas cetaben, due to its cytotoxicity, significantly decreases its activity (see tab. 1). This differential effect is more pronounced in MH1Cl cells indicating that rat cells are more sensitive to peroxisomal proliferators. On the other hand the activity of catalase, a peroxisomal marker, is increased in HepG2 cells by cetaben and clofibric acid, which is caused by a much higher response of mRNA synthesis (see tab. 1 and 2), and additionally the response of mRNA by clofibric acid treated cells is much higher than the increase in activity. Moreover the activities of the peroxisomal bifunctional enzyme in both cell lines are unaffected, although the mRNA level was enhanced to 2.3 fold by $10 \mu \mathrm{mol} / 1$ cetaben in HepG2 cells. In order to elucidate whether the increase of the activities of peroxisomal enzymes in hepatoma cell lines is weaker than in primary hepatocytes (34) or whether the increase is delayed, as suggested by the higher mRNA levels, long term studies have to be carried out.

It seems that the proliferation of the peroxisomal bifunctional enzyme is more pronounced if compared to other enzymes like succinate dehydrogenase (at $10 \mu \mathrm{mol} / \mathrm{l}$ cetaben enzyme activity is $75 \%$ of control).

Interestingly the response of thiolase to clofibric acid and cetaben is higher in $\mathrm{MH} 1 \mathrm{Cl}$ cells whereas the response in HepG2 varies. The decrease of the activity of thiolase at $100 \mu \mathrm{mol} / \mathrm{l}$ cetaben seems to be due to the high cytotoxicity. Cetaben also increases the activity of the peroxisomal $\beta$-oxidation system but this effect is compensated by the cytotoxicity of the compound.

At the concentrations used triiodothyronine does not trigger any response at all, which can be explained by the difference in the receptor mediated response (12). The effect of hypolipidaemic drugs seen in our cell model is less pronounced than in rat liver but stronger in the rat cell line $\mathrm{MH1Cl}$ than in the human cell line HepG2, but is in accordance with previous findings of Graham et al. (20) in primates and of Hanefeld et al. (35) in humans which indicates that the peroxisomal proliferation in human and primate is not as pronounced as in rat, although the lipid lowering effect is present in human (5). The hypotriglyceridaemic action of the se drugs is reported to be due to the decrease of apolipoprotein C-III gene expression, which was demonstrated by Staels et al. (36) in rat and human hepatocytes. Therefore this weak response of HepG2 to peroxisomal proliferators is in accordance with the assumed effect in human liver in vivo. Similar findings using human and rat hepatic cell lines have been previously reported by Scotto et al. (37) using clofibrate and Brocard et al. (38) using ciprofibrate.

Our results indicate that the human hepatoma cell line HepG2, as previously indicated by Watkins et al. (39), is an appropriate model for studies of the influence of hypolipidaemic agents on the peroxisomal enzyme system.

\section{Acknowledgements}

The authors would like to thank Ms. Maria Pedru for excellent technical assistance. Cetaben was kindly provided by American Cyanamid Company, Lederle Laboratories Division, Pearl River, USA. The cDNA for the rat acyl-CoA oxidase was a gracious gift from Prof. T. Osumi, the cDNA for the rat catalase was kindly 
provided by Dr. S. Furuta. The authors would like to thank Dr. G. Höfler for his generous gift of $\mathrm{CDNA}$ for the human peroxisomal bifunctional enzyme. The cDNA for human catalase was donated by Prof. I. Singh.

\section{References}

1. Lazarow PB, Fujiki F. Biogenesis of peroxisomes. Ann Rev Cell Biol 1985; 1:489-530.

2. Kramar R. Die Beteiligung der Peroxisomen am Lipidstoffwechsel. J Clin Chem Clin Biochem 1986; 24:109-18.

3. Reddy JK, Mannaerts GP. Peroxisomal lipid metabolism. Annu Rev Nutr 1994; 14:343-70.

4. Sirtori CR, Galli C, Franceschini G. Fraudulent (and non fraudulent) fatty acids for human health. Eur $\mathrm{J}$ Clin Invest 1993; 23:686-9.

5. Sirtori CR, Manzoni C, Lovati MR. Mechanisms of lipidlowering agents. Cardiology 1991; 78:226-35.

6. Hawkins JM, Jones WE, Bonner FW, Gibson GG. The effect of peroxisome proliferators on microsomal, peroxisomal, and mitochondrial enzyme activities in the liver and kidney. Drug Metabol Rev 1987; 18:441-515.

7. Fort FL, Stein HH, Langenberg K, Lewkowski JP, Heyman IA, Kesterson JW. Cetaben versus clofibrate comparison of toxicity and peroxisome proliferation in rats. Toxicology 1983; 28:305-11.

8. Chandoga J, Hampl L, Turecky L, Rojekova I, Uhlikova E, Hocman G: Cetaben is an exceptional type of peroxisome proliferator. Int J Biochem 1994; 26:679-96.

9. Just WW, Hartl FU, Schimassek H. Rat liver peroxisomes. I. New peroxisome population induced by thyroid hormones in the liver of male rats. Eur J Cell Biol 1982; 26:249-54.

10. Kramar R, Kremser K, Hohenegger M, Mayer M. Fatty acylCoA oxidase in rat kidney and liver after application of thyroxine. Enzyme 1986; 35:27-33.

11. Hryb DJ, Hoff JF. Chain length specificities of peroxisomal and mitochondrial $\beta$-oxidation in rat liver. Biochem Biophys Res Comm 1979; 87:1200-6.

12. Meier-Heusler SC, Zhu X, Juge-Aubry C, Pernin A, Burger AG, Cheng SY, Meier CA. Modulation of thyroid hormone action by mutant thyroid hormone receptors, c-erbAa2 and peroxisome proliferator-activated receptor: evidence for different mechanisms of inhibition. Mol Cell Endocrinol 1995; 107:55-66.

13. Van den Bosch $H$, Schutgens RBH, Wanders RJA, Tager JM. Biochemistry of peroxisomes. Annu Rev Biochem 1992; 61:157-97.

14. Osumi $\mathrm{T}$, Ishii $\mathrm{N}$, Miyazawa $\mathrm{S}$, Hashimoto $\mathrm{T}$. Isolation and structural characterization of the rat acyl-CoA oxidase gene. J Biol Chem 1987; 262:8138-43.

15. Schepers L, Van Veldhoven PP, Casteels M, Eyssen HJ, Mannaerts GP. Presence of three acyl-CoA oxidases in rat liver peroxisomes. An inducible fatty acyl-CoA oxidase, a noninducible fatty acyl-CoA oxidase, and a noninducible trihydroxycoprostanoyl-CoA oxidase. J Biol Chem 1990; 265:5242-6

16. Ishii $\mathrm{N}$, Hijikata $M$, Osumi $\mathrm{T}$, Hashimoto $\mathrm{T}$. Structural organization of the gene for rat enoyl-CoA hydratase: 3-hydroxyacyl-CoA dehydrogenase bifunctional enzyme. J Biol Chem 1987; 262:8144-50.

17. Hijikata M, Wen JK, Osumi T, Hashimoto T. Rat peroxisomal 3-ketoacyl-CoA thiolase gene. Occurrence of two closely related but differentially regulated genes. J Biol Chem 1990; 265:4600-6.

18. Bout A, Franse MM, Collins J, Blonden L, Tager JM, Benne $R$. Characterization of the gene encoding human peroxisomal 3-oxoacyl-CoA thiolase (ACAA). No large DNA rearrangement in a thiolase-deficient patient. Biochim Biophys Acta $1991 ; 1090: 43-51$.

19. Casteels M, Schepers L, Van Veldhoven P, Eyssen HJ, Mannaerts GP. Separate peroxisomal oxidases for fatty acyl-CoAs and trihydroxycoprostanoyl-CoA in human liver. $\mathrm{J}$ Lipid Res $1990 ; 31: 1865-72$.
20. Graham MJ, Wilson SA, Winham MA, Spencer AJ, Rees JA, Old SL, et al. Lack of peroxisome proliferation in marmorset liver following treatment with ciprofibrate for 3 years. Fundam Appl Toxicol 1994; 22:58-64.

21. Kremser K, Schön HJ, Lohninger A, Prager CM, Kramar R, Böck P. Response to thyroxine of lamellar bodies, peroxisomes and peroxisomal enzymes in the adult rat lung. Eur $\mathrm{J}$ Clin Chem Clin Biochem 1991; 29:151-8.

22. Lazarow PB. Different chain length specificities of peroxisomal and mitochondrial enoyl-CoA hydratases. Arch Biochem Biophys 1981; 206:342-5.

23. Lazarow PB. Rat liver peroxisomes catalyze the $\beta$-oxidation of fatty acids. J Biol Chem 1978; 253:1522-8.

24. Baudhuin $P$, Beaufay $H$, Rahman-Li $Y$, Sellinger $O Z$, Wattiqux $R$, Jacques $P$, et al. Tissue fractionation studies: intracellular distribution of monoamine oxidase, aspartate aminotransferase, alanine aminotransferase, D-amino acid oxidase and catalase in rat-liver tissue. Biochem J 1964; 92:169-84.

25. Bradford M. A rapid and sensitive method for the quantitation of microgram quantities of protein utilizing the principle of protein dye binding. Anal Biochem 1976; 72:248-54.

26. Sambrook J, Fritsch EF, Maniatis T. Molecular cloning. A laboratory manual. 2nd ed. Cold Spring Habor, New York: Cold Spring Harbor Laboratory, 1989.

27. Miyazawa S, Osumi T, Hashimoto T, Ohno K, Miura S, Sujiki Y. Peroxisome targeting signal of rat liver acyl-coenzyme $A$ oxidase resides at the carboxy terminus. Mol Cell Biol 1989; 9:83-91.

28. Hoefler $\mathrm{G}$, Forstner M, McGuinness MC, Hulla W, Hiden M, Krisper $\mathrm{P}$, et al. cDNA cloning of the human peroxisomal enoyl-CoA hydratase : 3-Hydroxyacyl-CoA dehydrogenase bifunctional enzyme and localization to chromosome 3q26.33q28: a free left Alu arm is inserted in the 3'noncoding region. Genomics 1994; 19:60-7.

29. Furuta S, Hayashi H, Hijikata M, Miyazawa S, Osumi T, Hasbimoto $\mathrm{T}$. Complete nucleotide sequence of $\mathrm{cDNA}$ and deduced amino acid sequence of rat liver catalase. Proc Natl Acad Sci USA 1986; 83:313-7.

30. Adams MD, Kelley JM, Gocayne JD, Dubnick M, Polymeropoulos $\mathrm{MH}$, Xiao $\mathrm{H}$, et al. Complementary DNA sequencing: expressed sequence tags and human genome project. Science $1991 ; 252: 1651-6$.

31. Minty AJ, Alonso S, Guenet $\pi$, Buckingham ME. Number of organization of actin-related sequences in the mouse genome. J Mol Biol 1983; 167:77-101.

32. Feinberg AP, Vogelstein B. A technique for radiolabelling DNA restriction endonuclease fragments to high specificity. Anal Biochem 1983; 132:6-13.

33. Mossman T. Rapid colorimetric assay for cellular growth and survival: application to proliferation and cytotoxicity assays. $J$ Immunol Meth 1983; 65:55-63.

34. Thangada S, Alvares $K$, Mangino M, Usman MI, Rao MS, Reddy JK. An in vitro demonstration of peroxisomes proliferation and increase in peroxisomal $\beta$-oxidation system mRNAs in cultured rat hepatocytes treated with ciprofibrate. FEBS Letters 1989; 250:205-10.

35. Hanefeld M, Kemmer C, Kadner E. Relationship between morphological changes and lipid-lowering action of p-chlorphenoxyisobutyric acid (CPIB) on hepatic mitochondria and peroxisomes in man. Atheriosclerosis 1983; 46:239-46.

36. Staels B, Vu-Dac N, Kosykh VA, Saladin R, Fruchart JC, Dallongeville J, Auwerx J. Fibrates downregulate apolipoprotein C-III expression independent of induction of peroxisomal acyl coenzyme A oxidase. J Clin Invest 1995; 95:705-12.

37. Scotto C, Keller JM, Schohn H, Dauca M. Comparative effects of clofibrate on peroxisomal enzymes of human (Hep EBNA2) 
and rat $(\mathrm{FaO})$ hepatoma cell lines. Eur J Cell Biol 1995; 66:375-81.

38. Brocard C, Es-Souni M, Ramirez LC. Latruffe N, Bournot P. Stimulation of peroxisomal palmitoyl-CoA oxidase activity by ciprofibrate in hepatic cell lines: comparative studies in Fao, $\mathrm{MH} 1 \mathrm{Cl}$ and HepG2 cells. Biol Cell 1993; 77:37-41.
39. Watkins PA, Ferrell EV, Pedersen JI, Hoefler G. Peroxisomal fatty acid $\beta$-oxidation in HepG2 cells. Arch Biochem Biophys $1991 ; 289: 329-36$.

Dr. Karl Kremser

Institut für Medizinische Chemie

der Universität Wien

Währingerstraße 10

A-1090 Wien

Austria 
